\title{
Response of endangered bird species to land-use changes in an agricultural landscape in Germany
}

\author{
Anne Jungandreas ${ }^{1} \cdot$ Stephanie Roilo $^{2}$ - Michael Strauch ${ }^{1} \cdot$ Tomáš Václavík $^{3,4} \cdot$ Martin Volk $^{1,5} \cdot$ Anna F. Cord ${ }^{1,2}$
}

Received: 13 October 2021 / Accepted: 16 January 2022 / Published online: 10 February 2022

(c) The Author(s) 2022

\begin{abstract}
Land-use intensification in agroecosystems has led to population declines in many taxonomic groups, especially farmland birds. Two contrasting conservation strategies have therefore been proposed: land sharing (the integration of biodiversity conservation in low-intensity agriculture) and land sparing (the spatial separation of high-yielding agriculture and areas for conservation). Despite the large academic interest in this field, only few studies have taken into account stakeholders' perspectives of these strategies when assessing conservation implications. We modeled the effects of three land-use scenarios (a business-as-usual, a land-sharing, and a land-sparing scenario), developed together with regional stakeholders, on the habitat area of 13 regionally endangered bird species in the Middle Mulde River Basin (Saxony, Germany). We used random forest models based on environmental variables relating to land-use/cover, climate and soil characteristics, occurrence of linear landscape elements (hedges and tree rows), and distance to water and major roads. Responses to the three land-use scenarios were species-specific, but extensively managed permanent grassland and the density of forest edges were positively associated with the occurrence of most bird species. Overall, the land-sharing scenario provided the largest breeding habitat area: $76 \%$ of the species had a significant $(p<0.05)$ increase in breeding habitat, and none showed a significant decrease. Our findings confirm that balancing the different, often contrasting habitat requirements of multiple species is a key challenge in conservation and landscape management. Land sharing, which local stakeholders identified as the most desirable scenario, is a promising strategy for the conservation of endangered birds in agricultural landscapes like our study region.
\end{abstract}

Keywords Agriculture $\cdot$ Biodiversity conservation $\cdot$ Land sharing $\cdot$ Land sparing $\cdot$ Land-use scenarios $\cdot$ Stakeholder

Communicated by Victor Resco de Dios

Stephanie Roilo

stephanie.roilo@tu-dresden.de

1 Department of Computational Landscape Ecology, UFZ Helmholtz Centre for Environmental Research, Permoserstr. 15, 04318 Leipzig, Germany

2 Chair of Computational Landscape Ecology, Institute of Geography, Technische Universität Dresden, Helmholtzstr. 10, 01069 Dresden, Germany

3 Department of Ecology and Environmental Sciences, Palacký University Olomouc, Slechtitelů 27, 78371 Olomouc, Czech Republic

4 Department of Climate Change Impacts On Agroecosystems, Global Change Research Institute of the Czech Academy of Sciences, Bělidla 986/4, 60300 Brno, Czech Republic

5 Institute for Geoscience and Geography, Martin-Luther-University Halle-Wittenberg, 06099 Halle (Saale), Germany

\section{Introduction}

Since 1962, the Common Agricultural Policy (CAP) has had a major impact on land use in the European Union (EU). Aided by CAP subsidies, the scale and intensity of agricultural operations have increased (e.g. holding size and agrochemical inputs; Pe'er et al. 2014). This development, together with crop specialization at both farm and landscape levels and the removal of semi-natural habitats, is one of the main causes of the dramatic population declines in European farmland birds in recent decades (Jerrentrup et al. 2017; Stjernman et al. 2019). The abolition of set-aside within the CAP in 2008 reduced food sources for many bird species and led to a loss of suitable nesting sites (Gillings et al. 2010). Along such international policy changes, the key driving factors of population declines are likely to vary regionally, as abiotic conditions such as topographic, pedo-climatic, and geomorphological features shape field and pasture size, type of cultivated crops, and farming practices at the local 
scale (Busch et al. 2020). While there is ample evidence that farmland biodiversity declines with increasing landuse intensity and homogeneization of the landscape, little is known about the shape of this relationship (Kleijn et al. 2012), which is likely species- and context-dependent, varying with the land-use history of each region (Batáry et al. 2017; Finch et al. 2020). Moreover, heterogeneous agricultural landscapes have been recognized as a valuable habitat for farmland birds, indicating that a certain level of land-use/ management is not only tolerated but also necessary for the subsistence of certain species (Stjernman et al. 2019).

Birds are considered good proxies to measure ecosystem integrity and play vital roles in the structuring and functioning of ecosystems (Vallecillo et al. 2016); a decline in their numbers is likely to reduce key ecosystem processes and services such as decomposition, pest control, pollination, and seed dispersal. For many farmland birds, extensive grasslands offer foraging and nesting habitats (Vickery et al. 2001). Linear landscape elements (e.g. tree rows, hedges) and scattered trees are known as biodiversity hotspots in agricultural landscapes (Ernst et al. 2017). They often have higher total abundance and species richness, as they offer a range of benefits for nesting, roosting, and maintaining connectivity and therefore may allow forest and forest-edge bird species to extend their range into the agricultural landscape (Wilson et al. 2017). In addition, rural villages and old farmsteads are important habitats for many farmland birds (Rosin et al. 2016). Modeling the distribution of bird species in agricultural landscapes is a particular challenge due to the high inter-annual variability of crops and agricultural management. However, species distribution models (SDMs), which are established tools in biogeography, landscape ecology, and conservation biology (Elith and Leathwick 2009), have been used as a species-based approach to develop a European-wide habitat quality indicator for common birds (Vallecillo et al. 2016). Previous studies have also shown that environmental suitability modeled with SDMs is linked to key reproduction parameters of birds (e.g. breeding output and territory size; Brambilla and Ficetola 2012).

Two contrasting management strategies to reconcile agricultural production and biodiversity conservation in agricultural landscapes have been proposed and have led to a heated scientific debate (Fischer et al. 2014). In a land-sparing (LSP) strategy, some land is set aside for conservation while other land is used intensively to produce agricultural commodities; in a land-sharing (LSH) strategy, low-yielding and less intensive production techniques are used to maintain biodiversity within agricultural land. However, there is a wide variation in definitions of what constitutes spared or shared land. While some researchers argue that only (semi)natural habitats should be used to represent land-sparing strategies (Phalan et al. 2011), others have used grazed/managed grasslands (Kamp et al.
2015) or low-intensity farmland with sparse vegetation (Jerrentrup et al. 2017) to represent land sparing. The same variety of definitions applies to land sharing, which has been exemplified by organic farming (Gabriel et al. 2013), silvopastures (Macchi et al. 2013), woodland islets in agricultural land (Rey Benayas and Bullock 2012), or landscapes with low human population densities (Chapron et al. 2014). The discussion on which land-use strategy offers the best integration between agricultural yields and biodiversity protection is further complicated by the different perspectives of stakeholders, which depend largely on their preferred management goals (Manning et al. 2018). However, their involvement in environmental planning is important because (i) stakeholders with different views can help to find balanced and realistic outcomes, (ii) their contribution can help to avoid conflicts later on, and (iii) they often have information on the local needs and opinions in the region that is otherwise not readily available (Jolibert and Wesselink 2012; Vogler et al. 2017). Especially in scenario planning at the local scale, stakeholders can help to consider desirable and undesirable future aspects and relevant trade-offs (Bennett et al. 2016). Nevertheless, stakeholders were rarely involved in LSH/LSP studies and in the development of regional land-use management scenarios (but see Karner et al. 2019), which limits the practical applicability of the concept (e.g. criticized in Scariot 2013; Fischer et al. 2014) and the credibility of future forecasts in the local context (Volkery et al. 2008).

In this study, we model the impacts of three stakeholderdriven land-use scenarios (business-as-usual, which follows the current trends of development-LBA, LSH, and LSP) on the breeding habitat area of 13 regionally endangered bird species in the Middle Mulde River Basin, a rural area in Central Germany. The three land-use scenarios were developed in a stakeholder co-design process as described in Karner et al. (2019). We agree with previous studies (e.g. Rey Benayas and Bullock 2012; Fischer et al. 2014) that land sharing and land sparing should not be seen as mutually exclusive alternatives, but as a set of measures that can be combined to best reconcile agricultural production and biodiversity conservation in agroecosystems. We use them here to illustrate and assess the potential impacts of a range of available and realistic management options. Our research questions are as follows:

1. What are the main environmental variables that determine the habitat of each endangered bird species in the Middle Mulde River Basin?

2. How will species-specific habitat area change in the three land-use scenarios?

3. Which land-use scenario overall provides the largest habitat area, since all species have different and sometimes contradictory habitat preferences and requirements? 


\section{Materials and methods}

\section{Study area}

The Middle Mulde River Basin is located in the federal state of Saxony, Germany, and comprises an area of $1,624 \mathrm{~km}^{2}$ (Fig. 1). The average annual precipitation varies between 570 and $880 \mathrm{~mm}$ and depends mainly on the altitude, which ranges from 70 to $505 \mathrm{~m}$ asl. The presence of fertile loess soils favours intensive arable farming (especially winter wheat, rapeseed, winter barley, and corn). The area is therefore mostly covered with cropland (54\%), and with permanent grassland (14\%), especially in the Mulde floodplains. About $10 \%$ of the area is used for settlements or road infrastructure. Only $20 \%$ is covered with forest, which is well below the average of forest cover in Saxony (28\%) and Germany (31\%) (SMUL 2016). The afforestation of deciduous forests is therefore one of the political goals of the federal state of Saxony until 2050 (SMUL 2016). At the same time, the increasing land consumption for settlements-in Saxony on average
$4.3 \mathrm{ha} /$ day (Meinel et al. 2018)—causes high losses of agricultural land and leads to habitat loss for biodiversity. About $10 \%$ of the study area is protected as part of Natura2000 sites, which cover the entire length of the Mulde River within the study region and the Pressel heathlandwoodland complex and peatlands in the north (Sächsisches Landesamt für Umwelt, Landwirtschaft und Geologie 2011). Around 240 bird species live in this area, 47 of which are listed in the Saxon Red List of Breeding Birds in the categories 'endangered', 'critically endangered', or 'threatened with extinction' (Sächsisches Landesamt für Umwelt, Landwirtschaft und Geologie 2015) (Table 1). The Middle Mulde River Basin is therefore an ideal region to study the effects of future land use on endangered birds, with the main drivers being agricultural intensification, settlement expansion, and afforestation.

\section{Stakeholder-driven land-use scenarios}

Based on the status quo land use reflecting the year 2010 and described in the "Land-use predictors" section (Fig. 1), three land-use scenarios were developed for the year 2030
Fig. 1 Land use in the Middle Mulde River Basin in Saxony, Germany, based on the reference year 2010, and location of the study region within Germany
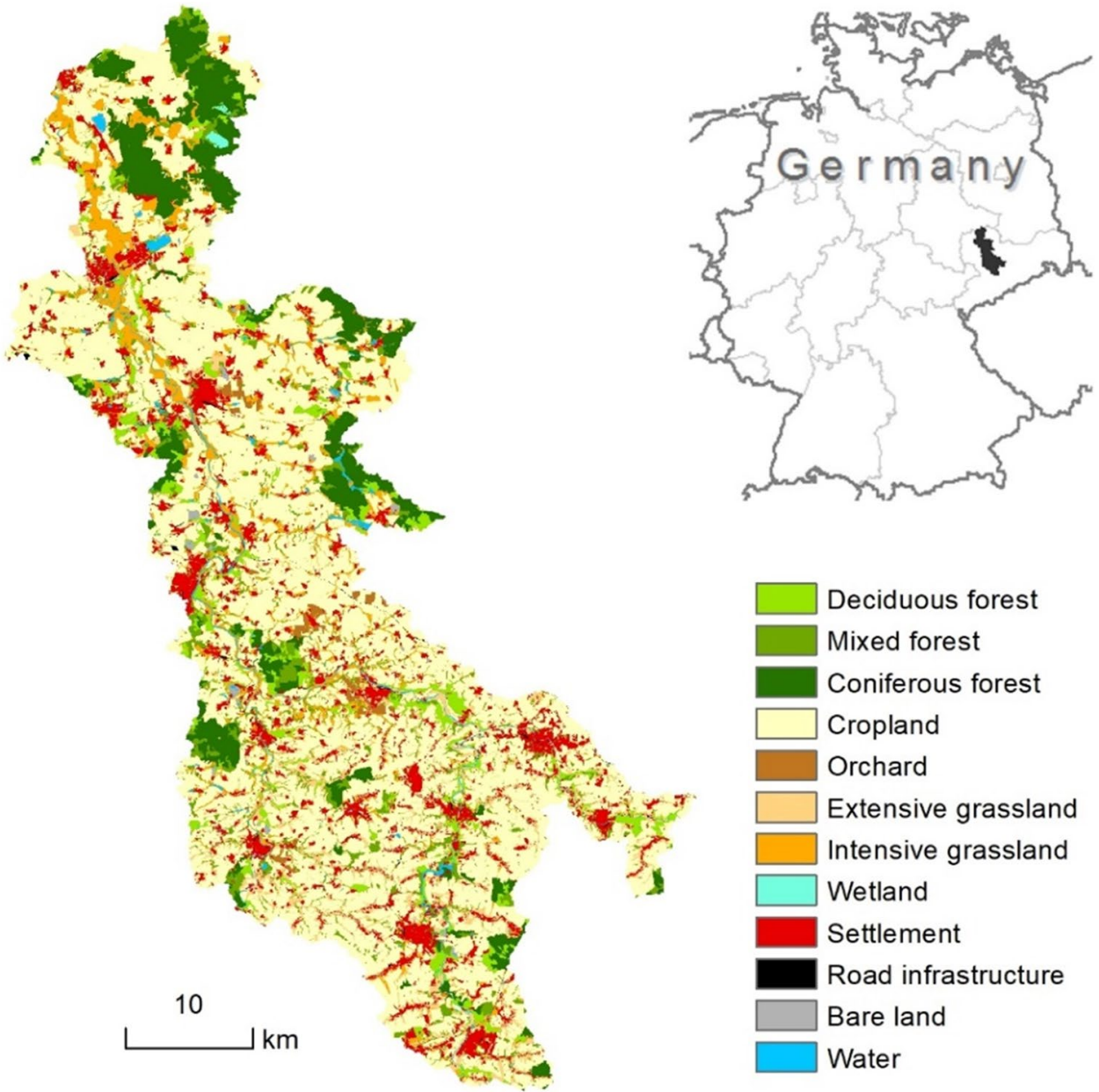

Deciduous forest Mixed forest Coniferous forest Cropland Orchard Extensive grassland Intensive grassland Wetland Settlement Road infrastructure Bare land Water 
Table 1 Endangered bird species included in the present study, including information on the number of presence records (i.e. occurrence points collected between 2003 and 2008 and used for modelling) and the conservation status according to the Saxon Red List of
Breeding Birds (Sächsisches Landesamt für Umwelt, Landwirtschaft und Geologie 2015). Habitat description and habitat requirements are from Steffens et al. (1998)

\begin{tabular}{|c|c|c|c|}
\hline Bird species (abbreviation, common name) & $\begin{array}{l}\text { Number of } \\
\text { presence } \\
\text { records }\end{array}$ & Conservation status & Habitat description and requirements \\
\hline Alcedo atthis (Aa, common kingfisher) & 271 & Endangered & $\begin{array}{l}\text { Breeding holes are on riverbanks or in open pits; } \\
\text { always close to surface water; preference for the } \\
\text { presence of overhanging branches }\end{array}$ \\
\hline $\begin{array}{l}\text { Acrocephalus schoenobaenus (As, sedge war- } \\
\text { bler) }\end{array}$ & 60 & Endangered & $\begin{array}{l}\text { Settles in/next to silt up shores of lakes with reeds } \\
\text { and shrubs on land }\end{array}$ \\
\hline Coloeus monedula ( $\mathrm{Cm}$, western jackdaw) & 52 & Endangered & $\begin{array}{l}\text { Favors high buildings for nesting; grasslands are } \\
\text { the main foraging habitat }\end{array}$ \\
\hline Galerida cristata (Gc, crested lark) & 69 & Threatened with extinction & $\begin{array}{l}\text { Ground-breeding bird on dry, warm soils with } \\
\text { sparse vegetation }\end{array}$ \\
\hline Gallinago gallinago ( $G g$, common snipe) & 53 & Threatened with extinction & $\begin{array}{l}\text { Ground-breeding bird in wetland or in open } \\
\text { grassland with wet soil; linear landscape ele- } \\
\text { ments (trees rows, hedgerows) increase habitat } \\
\text { suitability }\end{array}$ \\
\hline Hirundo rustica ( $\mathrm{Hr}$, barn swallow) & 74 & Endangered & $\begin{array}{l}\text { Nests usually in buildings, often in livestock } \\
\text { farms and small houses in villages; grasslands } \\
\text { and water bodies are the main foraging habitat }\end{array}$ \\
\hline Lullula arborea ( $L a$, wood lark) & 125 & Endangered & $\begin{array}{l}\text { Nests in sparsely covered areas (clear-cut forests, } \\
\text { open pits, etc.) with a preference for dry, sandy } \\
\text { soil }\end{array}$ \\
\hline Oenanthe oenanthe (Oo, northern wheatear) & 35 & Threatened with extinction & $\begin{array}{l}\text { Nests in caves and prefers the open countryside } \\
\text { with spots of bare soil and linear landscape ele- } \\
\text { ments; often found in open pit-mining areas }\end{array}$ \\
\hline $\begin{array}{l}\text { Phoenicurus phoenicurus (Pp, common red- } \\
\text { start) }\end{array}$ & 77 & Endangered & $\begin{array}{l}\text { Nests in cavities; prefers open forest, parks, gar- } \\
\text { dens, and orchards; often found in settlements }\end{array}$ \\
\hline Saxicola rubetra ( $\mathrm{Sr}$, whinchat) & 217 & Critically endangered & $\begin{array}{l}\text { Ground-breeding with a preference for humid } \\
\text { grassland with linear landscape elements }\end{array}$ \\
\hline Streptopelia turtur (St, turtle dove) & 122 & Endangered & $\begin{array}{l}\text { Prefers forest margins and nests in trees; avoids } \\
\text { settlements }\end{array}$ \\
\hline Tyto alba (Ta, barn owl) & 166 & Critically endangered & $\begin{array}{l}\text { Nests in settlements with surrounding open coun- } \\
\text { tryside; avoids closed forests }\end{array}$ \\
\hline Vanellus vanellus ( $V v$, lapwing) & 36 & Threatened with extinction & $\begin{array}{l}\text { Ground-breeding bird on wetland, grass- and } \\
\text { cropland; prefers humid soils }\end{array}$ \\
\hline
\end{tabular}

by applying a participatory co-design approach described in detail in Karner et al. (2019). In short, stakeholders representing local and regional public administration bodies from the agricultural, forestry, environmental, and political sectors, as well as NGOs, developed explorative land-use scenarios based on contrasting developments of agricultural input and output prices, direct payment funding, greening requirements, agri-environmental program funding, environmental and nature protection legislation, EU food consumption, and other aspects until 2030 (Karner et al. 2019). The scenarios were designed as three possible future developments along the land sharing/sparing gradient. The stakeholders agreed upon (i) total amounts of change per land-use class for each land-use scenario and (ii) priority areas for specific land-use transitions based on current land use. In the LBA scenario, which follows the current trends of development, stakeholders forecasted an expansion in settlements and an increase in deciduous forest (as part of the Saxon afforestation program), with a concurrent reduction of cropland and a decrease in the number of linear landscape elements (Table 2). The LSP scenario was defined by agricultural intensification and homogenization of the landscape, i.e. conversion from grassland to cropland in areas with high soil fertility, intensification in the management of the remaining grassland, and a considerable reduction in the number of linear landscape elements. Of the three scenarios, LSP involved the largest increase in semi-natural cover, specifically deciduous forest, at the expense of agricultural land ('set aside' area), and no change in urban cover. Finally, the LSH scenario was characterized by agricultural extensification, i.e. extensive management of formerly high-intensity grasslands, reduction in cropland area, and increase in the 
Table 2 Changes in land use, number of linear landscape elements, and density of forest edges in the different scenarios. Values in brackets represent the change compared to the status quo

\begin{tabular}{|c|c|c|c|c|}
\hline & Status quo & $\begin{array}{l}\text { Business as usual } \\
( \pm \text { change })\end{array}$ & Land sparing ( \pm change) & Land sharing ( \pm change) \\
\hline \multicolumn{5}{|l|}{ Proportion (\%) of land covered by: } \\
\hline Agricultural area & 68.6 & $63.8(-4.8)$ & $63.9(-4.7)$ & $65.4(-3.2)$ \\
\hline Cropland & 54.0 & $49.2(-4.8)$ & $57.4(+3.4)$ & $50.8(-3.2)$ \\
\hline Orchard & 0.8 & 0.8 & $1.5(+0.7)$ & 0.8 \\
\hline Grassland & 13.8 & 13.8 & $5.0(-8.8)$ & 13.8 \\
\hline Extensive grassland & 7.0 & 7.0 & $0.0(-7.0)$ & $13.8(+6.8)$ \\
\hline Intensive grassland & 6.8 & 6.8 & $5.0(-1.8)$ & $0.0(-6.8)$ \\
\hline Semi-natural cover & 21.4 & $23.8(+2.4)$ & $26.1(+4.7)$ & $23.8(+2.4)$ \\
\hline Forest & 19.6 & $22.0(+2.4)$ & $24.3(+4.7)$ & $22.0(+2.4)$ \\
\hline Deciduous forest & 4.6 & $7.0(+2.4)$ & $9.3(+4.7)$ & $7.0(+2.4)$ \\
\hline Mixed forest & 5.8 & 5.8 & 5.8 & 5.8 \\
\hline Coniferous forest & 9.2 & 9.2 & 9.2 & 9.2 \\
\hline Wetland & 0.1 & 0.1 & 0.1 & 0.1 \\
\hline Bare land & 0.4 & 0.4 & 0.4 & 0.4 \\
\hline Water body & 1.3 & 1.3 & 1.3 & 1.3 \\
\hline Urban cover & 10.1 & $12.5(+2.4)$ & 10.1 & $10.9(+0.8)$ \\
\hline Settlement & 9.9 & $12.3(+2.4)$ & 9.9 & $10.7(+0.8)$ \\
\hline Road infrastructure & 0.2 & 0.2 & 0.2 & 0.2 \\
\hline \multicolumn{5}{|l|}{ Linear landscape elements: } \\
\hline Proportion by area (A) (\%) & 0.42 & $0.37(-0.05)$ & $0.11(-0.31)$ & $0.67(+0.25)$ \\
\hline Proportion by perimeter $(\mathrm{P})\left(\mathrm{m}^{2} / \mathrm{m}\right)$ & 0.24 & $0.20(-0.04)$ & $0.08(-0.16)$ & $0.39(+0.15)$ \\
\hline Density of forest edges $\left(\mathrm{m}^{2} / \mathrm{m}\right)$ & 15.5 & $24.4(+8.9)$ & $18.5(+2.9)$ & $21.4(+5.8)$ \\
\hline
\end{tabular}

number of linear landscape elements. In addition, forest and (to a lesser extent than in the LBA scenario) settlements were assumed to be established on former cropland in the LSH scenario. Several land-use classes (e.g. water body, bare land) were not changed in any of the scenarios.

The location of the land-use change within the Middle Mulde River Basin was determined by a set of spatial rules taking into account the following criteria: distance to existing land-use classes, distance to existing road infrastructure, soil productivity, and soil erosion risk. For example, the conversion of cropland to settlement was assumed to occur near existing settlements, near existing roads, and on soils with low productivity. Following this logic, we calculated the conversion potential (CP) for each grid cell using a multi-criteria evaluation approach (Jiang and Eastman 2000). This approach allowed (i) ranking the values of all considered criteria in a standardized way and (ii) weighting them in order to modulate the magnitude of their effect on the conversion potential, calculated as follows:

$C P=w_{1} x_{1}+w_{2} x_{2} \cdots+w_{n} x_{n}$

where $x$ is the criterion score standardized to a range between 0 and 100 (higher values representing a higher conversion potential) and $w$ is the weight assigned to each criterion. We used $w=1$ for simplicity to give the same weight to all considered criteria. Once $\mathrm{CP}$ was determined for each land-use conversion and scenario, we converted the appropriate amount of land (based on Table 2) in locations with the highest CP. All spatial analyses were conducted in ArcGIS 10.4 (ESRI, Redlands, CA) and Python (Python Software Foundation, version 2.7, http://www.python.org). This procedure resulted in three land-use maps for the year 2030 with 25-m cell size (Supplementary file S1). The extent of land-use change in the different scenarios is summarized in Table 2.

\section{Bird occurrence data}

The bird data were collected as part of the breeding bird monitoring and Natura 2000 monitoring projects led by the Saxon State Agency for Environment, Agriculture and Geology (Steffens et al. 2013; Ulbricht 2018). We considered all endangered bird species with more than 30 observations after removing pseudo-replicates (i.e. multiple records in the same environmental raster cell), for the period 2003-2008, which led to 13 study species (Table 1 ). Since no information on the absence of species was available, we used coordinates of observation points of other species as absences, 
excluding data within a radius of $500 \mathrm{~m}$ around the presence coordinates of each focal species ('target-group background'; Barbet-Massin et al. 2012). This approach is an effective means to reduce the influence of spatially biased samples, e.g. towards more accessible or protected areas, as is typical for citizen science-derived data and monitoring projects at national and subnational levels (Ranc et al. 2017). To avoid model overfitting (Barbet-Massin et al. 2012), we used only 300 absence records, randomly selected from the full dataset of absences.

\section{Environmental predictors}

Based on the habitat requirements of our study species (Table 1), we identified pedo-climatic characteristics, distance-related parameters, and land-use characteristics as particularly important for modeling habitat suitability. To avoid using collinear variables in the same model, we calculated the Pearson's correlation coefficient for each pair of variables and removed variables with $|r|>0.85$ (Supplementary file S2), following other studies employing machine learning methods (Elith et al. 2006).

\section{Pedo-climatic characteristics and distance-related parameters}

From 49 precipitation and 17 climate stations of the German Weather Service (Deutscher Wetterdienst, https://www.dwd. de), information on multiannual mean temperature, temperature range, and average annual precipitation sum between 1980 and 2005 was retrieved. We corrected precipitation for sampling errors according to Richter (1995) and aggregated all three parameters to the level of sub-watersheds using the Thiessen polygon method in R Version 3.4.1 (R Core Team 2016). We further used the BK50 digital soil map (Digitale Bodenkarte 1:50.000 für den Freistaat Sachsen 2012, Sächsisches Landesamt für Umwelt, Landwirtschaft und Geologie) in combination with pedotransfer functions (Eckelmann et al. 2005) to obtain spatially explicit parameters for the top soil, namely bulk density, available water capacity, saturated hydraulic conductivity, and organic carbon content. Distance to water bodies (both standing and running surface water) and to main roads was calculated based on the land-use information described in the following section "Land-use predictors" in ArcGIS 10.3.1. Given the scope of this study, we left all climate and soil parameters unchanged in the scenario development, focusing solely on land-use change.

\section{Land-use predictors}

To describe the status quo land use, we used a land cover map at 25-m resolution reflecting the year 2010 (Fig. 1), which combined information from the ATKIS Basis DLM
(Digitales Basis-Landschaftsmodell des Amtlichen Topographisch-Kartographischen Informationssystems 2010, Arbeitsgemeinschaft der Vermessungsverwaltungen der Länder der Bundesrepublik Deutschland), CORINE Land Cover data (CLC 2012 Version 18.5.1, European Environment Agency), and a colour-infrared (CIR) biotope and land-use map (Biotoptypen- und Landnutzungskartierung 2005, Sächsisches Landesamt für Umwelt, Landwirtschaft und Geologie). For linear landscape elements, we used information on tree rows and hedgerows from the ATKIS Basis DLM as in Jerrentrup et al. (2017). Assuming a standard width of $5 \mathrm{~m}$, we calculated the proportion of linear landscape elements by area, but also by perimeter at the level of hydrological response units (HRUs). We chose HRUs, as used in the Soil and Water Assessment Tool-SWAT (Bieger et al. 2017), as spatial units of analysis because we aim to simulate the combined effects of land-use changes on biodiversity (modeled in this study) and ecosystem services (according to the SWAT model) in future studies. The development of the LBA, LSP, and LSH scenarios is based on this land-use map, and differences in the proportion of land cover types across the scenarios are summarized in Table 2.

\section{Species distribution models}

We used random forest (RF) (Breiman 2001), a machine learning method that is on par with or better than other algorithms used to model species distributions, especially for species with few observation points (Mi et al. 2017). We fitted the RF models as regression models with 500 trees. The number of variables randomly sampled as candidates at each split was the total number of variables which entered the model (reported under 'remaining variables' in Table 3) divided by 3. All analyses were performed in R (R Core Team, 2016) using the randomForest package (Liaw and Wiener 2002).

Predictor selection We used the backwards feature selection (rfe() function) from the caret package (Kuhn 2016) to identify the most influential predictors for each species. This method was shown to be effective for variable selection in RF models and to reduce the effect of variable correlation on the importance measure (Gregorutti et al. 2017). In this approach, RF models are first built using the full set of environmental variables (Table 3, left). Based on the total decrease of node impurities $(\mathrm{MDI}=$ mean decrease impurity), variables are then ranked by importance. Highly important variables will create 'purer' nodes (with higher MDI value) than less important ones. At each step, we assessed two measures of model accuracy: the RMSE (root mean squared error) and the pseudo- $R^{2}$ (pseudo-coefficient of determination). We repeated the feature selection ten times with different random sets of absences to ensure 
Table 3 Variable importance and model accuracy measures of the random forest models. The table lists the mean variable importance (indicated by the mean decrease impurity) for all environmental variables, the mean area under the curve (AUC) of the receiver operating characteristic and the mean pseudo- $R^{2}$ and root mean squared error (RMSE) values of the ten models per species. Species abbre- viations are explained in Table 1. The two most important variables per species are highlighted in bold. Only the variables marked with * changed in the land-use scenarios. Mean and standard deviation values of the evaluation metrics and the variable importance scores are reported in Supplementary files S3 and S4

\begin{tabular}{|c|c|c|c|c|c|c|c|c|c|c|c|c|c|}
\hline & $A a$ & As & $\mathrm{Cm}$ & $G c$ & $G g$ & $H r$ & $L a$ & Oo & $P p$ & $S r$ & $S t$ & $T a$ & $V v$ \\
\hline \multicolumn{14}{|l|}{ Land use } \\
\hline Cropland * & 6.0 & 3.9 & 5.1 & 2.6 & - & 2.4 & 2.4 & 2.0 & 2.4 & 5.7 & 3.6 & 4.1 & 5.4 \\
\hline Orchard & - & - & - & - & - & - & - & - & - & - & - & - & - \\
\hline Grassland * & 8.2 & 5.6 & 1.9 & 2.2 & 1.9 & 2.2 & - & 1.4 & 2.5 & 7.3 & 5.8 & 3.2 & 3.0 \\
\hline Extensive * & - & 4.6 & - & - & - & 6 & - & 0.7 & 1.4 & 3.5 & - & - & - \\
\hline Intensive * & - & - & 0.5 & 1.5 & - & - & - & 1.3 & - & 4 & 0.8 & 2.1 & - \\
\hline Forest * & - & 3.6 & 0.9 & 4.7 & - & 1.3 & 12.2 & 1.3 & 6.9 & 6.3 & 22.9 & 6.2 & 1.7 \\
\hline Deciduous * & - & - & - & - & 0.3 & - & 1.7 & 0.2 & - & 1.6 & 0.7 & - & - \\
\hline Mixed & - & - & 0.4 & - & 1 & - & 2.3 & - & 2.7 & 3.2 & 1.9 & - & - \\
\hline Coniferous & - & - & - & - & 1.3 & - & - & 0.3 & 1.6 & 2.8 & 22.0 & - & - \\
\hline Wetland & - & - & - & - & 9.6 & - & - & - & - & - & - & - & 0.5 \\
\hline Bare land & - & - & 0.9 & - & - & - & - & 4.4 & - & 1.6 & - & - & - \\
\hline Water body & 21.8 & 3.5 & 0.3 & - & - & 0.8 & 0.8 & 0.8 & 0.8 & - & - & 2.8 & - \\
\hline Settlement $*$ & - & - & 11.9 & 10.8 & - & 9.8 & - & - & 2.8 & 7.6 & 1.2 & 31.4 & - \\
\hline Road infrastructure & - & - & - & - & - & - & - & - & - & - & - & - & - \\
\hline \multicolumn{14}{|l|}{ Linear elements } \\
\hline Share by area * & - & - & - & - & - & - & - & 0.6 & - & 11.5 & - & - & - \\
\hline Share by perimeter * & - & - & 0.3 & - & - & - & - & 0.7 & - & 12.3 & - & - & 2.1 \\
\hline Forest edges * & 12.1 & 3.1 & - & - & 0.5 & 1.1 & 2.8 & 1.2 & 3.7 & 3.6 & 0.6 & 2.4 & - \\
\hline \multicolumn{14}{|l|}{ Climate } \\
\hline Temperature & 11.1 & - & 1.7 & - & 0.3 & 5.1 & 5.7 & 1 & 2.5 & 3.2 & 2.4 & 4.9 & 1.4 \\
\hline Precipitation & - & - & 3.8 & 5.8 & 0.3 & 3 & 5.5 & 0.8 & 3.4 & 3.7 & 1.6 & 3.3 & 2.3 \\
\hline Temp. range & 13.8 & 8.5 & 0.8 & 2.5 & 1.2 & 6.3 & 17.1 & 1.1 & 2.5 & 4.1 & 5.6 & 2.3 & 1.7 \\
\hline \multicolumn{14}{|l|}{ Soil } \\
\hline Available water content & - & 5.6 & 2.1 & 2.7 & 4.3 & 5.5 & 4.7 & 0.6 & 1.7 & 5.1 & 0.7 & 11.1 & 2.5 \\
\hline Bulk density & - & - & 0.5 & - & 6.2 & - & - & 0.8 & 1.9 & 3.7 & 0.8 & - & - \\
\hline Carbon content & - & 1.8 & 0.8 & - & 9.1 & - & - & 0.2 & 1.4 & 2.8 & 0.9 & 4.3 & 1.9 \\
\hline Hydraulic conductivity & - & - & 1 & 1.9 & 0.3 & - & - & 1.2 & 1.7 & 3.7 & 1 & 6.8 & - \\
\hline \multicolumn{14}{|l|}{ Distance to ... } \\
\hline Next waterbody & 44.8 & - & 1.2 & 7.8 & 0.7 & 3.0 & 10 & 1.5 & 1.8 & 7 & 0.9 & 3.8 & 1.6 \\
\hline Major road & 6.5 & - & 2.3 & 3.6 & 0.5 & 3.2 & 9.5 & 2.7 & 8.1 & 4.1 & 0.9 & 3.3 & 1.9 \\
\hline \multicolumn{14}{|l|}{ Summary } \\
\hline Remaining variables & 8 & 9 & 18 & 11 & 15 & 13 & 12 & 21 & 18 & 22 & 18 & 15 & 8 \\
\hline \multicolumn{14}{|l|}{ RF models } \\
\hline AUC & 0.99 & 0.96 & 1 & 1 & 1 & 1 & 0.99 & 0.92 & 0.92 & 0.98 & 1 & 0.99 & 1 \\
\hline RMSE & 0.2 & 0.21 & 0.14 & 0.15 & 0.1 & 0.15 & 0.19 & 0.18 & 0.22 & 0.27 & 0.16 & 0.21 & 0.14 \\
\hline pseudo- $R^{2}[\%]$ & 83.7 & 64.2 & 82.9 & 83.1 & 90.3 & 83.1 & 81.3 & 61.4 & 67.3 & 69.3 & 87 & 80.3 & 75.2 \\
\hline
\end{tabular}

representative coverage of environmental conditions in the study area. For each repetition and each species, the best set of predictors was determined by using the smallest variable subset with a quality loss of less than $5 \%$ for both RMSE and pseudo- $R^{2}$. All predictors that remained at least once in the selected variable subset were included in the final set of variables for model training (Table 3 ). We also verified the selected predictor sets by comparing them with the reported habitat requirements of each species (Steffens et al. 1998) (Table 1). We produced partial dependence plots, which give a graphical depiction of the marginal effect of a variable on bird occurrence, using the partialPlot() function of the randomForest package (Liaw and Wiener 2002).

Model training and testing We randomly split presence records of each species into training (5/6 of the data) and 
testing data (1/6). For all selected predictors (Table 3), we estimated the proportion of area covered (e.g. for land use) or the mean value (e.g. for precipitation) within a radius of $250 \mathrm{~m}$ around each presence or absence point as input for the RF models. RF model training was repeated ten times, each with 300 different random absence records for each species (see the "Bird occurrence data" section). Each model was then evaluated by cross-validation using the test data. We calculated the area under the curve (AUC) of the receiver operating characteristic, a threshold-independent evaluation metric (Fletcher and Fortin 2018), using the evaluate() function from the dismo package (Hijmans et al. 2017). The mean values of AUC were calculated across the ten model runs. RF models, trained and tested for the status quo, were finally applied to the three land-use scenario maps (predict $($ ) function).

Breeding habitat area We used the 'maximum sensitivity and specificity' threshold to convert continuous predictions into binary presence/absence maps (threshold() function; dismo package). Since ten independent RF models existed for each bird species and land-use scenario, the average change in breeding habitat area was calculated from ten pairs of predictions. Using a Wilcoxon signed-rank test, we assessed whether this change from the status quo was significant. To ascertain which specific land-use change (e.g. loss of extensive grasslands) was responsible for the predicted habitat changes, we performed permutation tests and replaced one land-use-related variable at a time in the status quo with the values of the respective future scenario. The permutations were repeated 10 times for each substituted variable, using the previously trained and tested RF models. The change in the modeled breeding habitat area due to this sole replacement enabled us to identify the land-use changes with the greatest impacts.

\section{Results}

\section{Model accuracy and variable importance}

All models showed high accuracy, with AUC scores above 0.9 , and good predictive power with mean pseudo- $R^{2}$ values between 62 and $90 \%$ and RMSE values between 0.1 and 0.27 (Table 3; Supplementary file S3). Between 8 and 22 environmental variables were retained as model predictors for the different study species (Table 3; Supplementary file S4). The most frequently selected variables were the main land-use classes, climatic predictors, and distance-related parameters. Rare land-use classes (i.e. with low coverage in the study region) were only relevant for a few specialized species. For example, wetland was the most important predictor for the common snipe, which corresponds to its known habitat preferences. Similarly, bare land was the most important variable for the northern wheatear, which breeds in open, sparsely vegetated areas. Orchards and road infrastructures were not selected for any of the species. The settlement area strongly influenced species that commonly breed in or near buildings (western jackdaw, barn swallow, barn owl). The distance to main roads and to water bodies had effects on all species except for the sedge warbler, but with varying levels of importance (see Supplementary file S5 for partial dependence plots). Linear landscape elements like hedges and tree rows were chosen by the feature selection routine for only four species and had a high importance only for the whinchat (1st and 2nd rank). Forest edges, on the other hand, influenced the occurrence of ten study species of low to medium importance (3rd to 18th rank) and generally showed a positive correlation between species occurrence and density of forest edges (Supplementary file S5). Of the soil parameters, available water content was the most frequently selected predictor, but with varying importance (2nd to 15 th rank).

\section{Changes in breeding habitat area}

We found the largest increase in modeled habitat area for the crested lark in the LBA scenario (+53.8\%) and the largest decrease for the barn swallow in the LSP scenario $(-84.4 \%)$ (Fig. 2, left columns). Across all species, the total increase in modeled breeding habitat area was the largest according to the LSH scenario (Fig. 2c). Ten of the 13 study species had a significant $(p<0.05)$ increase in breeding habitat in this scenario, and none showed a significant decrease. It was the only scenario in which no species was significantly negatively affected. On the contrary, six species lost a significant part of their breeding habitat in the LSP scenario-while six other species gained habitat. In the LBA scenario, the size of the breeding habitat increased significantly for eight and decreased for three species.

\section{Relative importance of land-use changes}

The permutation tests showed that each species benefited from certain changes in land use and was negatively affected by others (Fig. 2). For example, of the species that gained breeding habitat in the LBA scenario (Fig. 2a), two species primarily benefited from the expansion of the settlement area $(G c, T a)$ and one from the afforestation $(P p)$, while two other species suffered from the loss of cropland $(O o, V v)$.

Focusing on bird species with significant expansion or reduction of their habitat (Fig. 3), we were also able to assess the effect of individual land-use variables across the three scenarios. For species gaining habitat area, the most relevant land-use changes were the increase of the settlement area (especially in the LBA scenario), the changes in cropland area (in all scenarios, but especially in LSP), and 

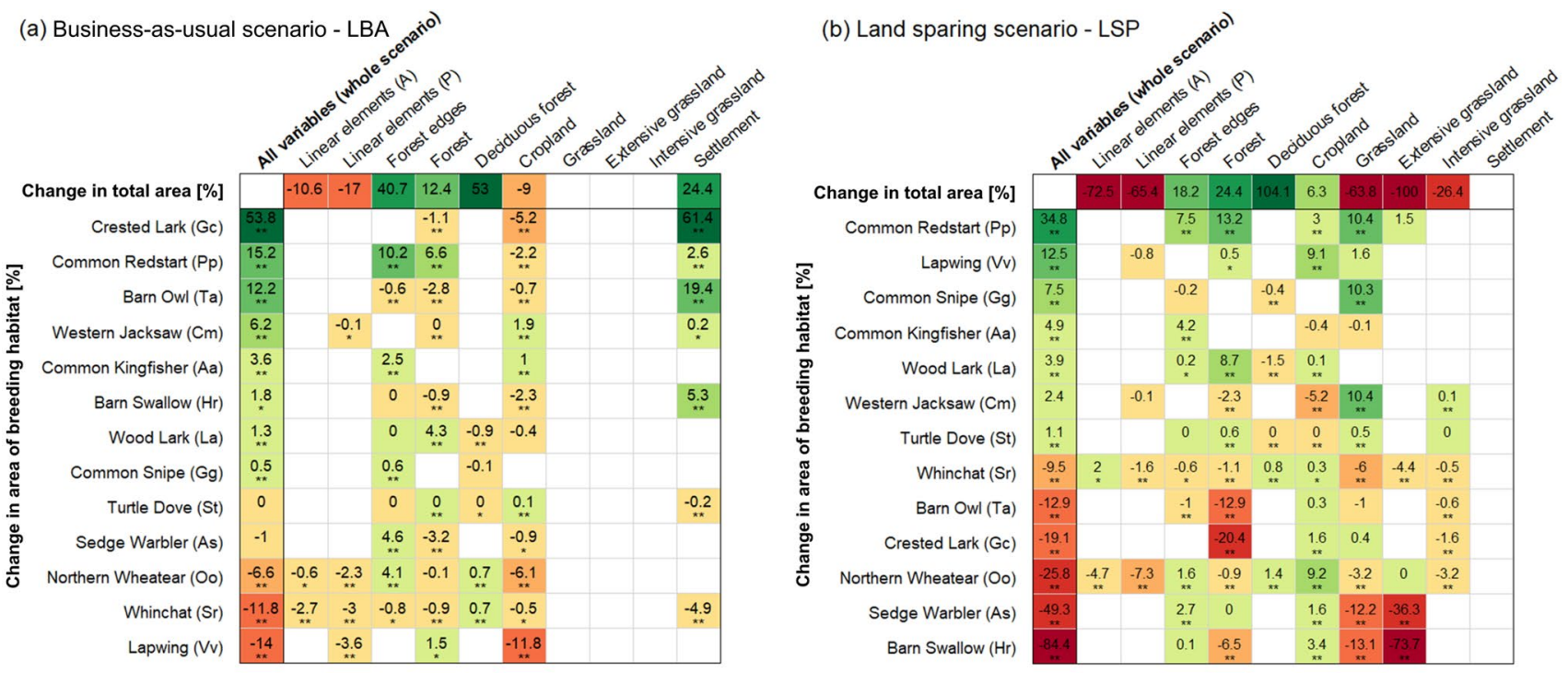

(c) Land sharing scenario - LSH

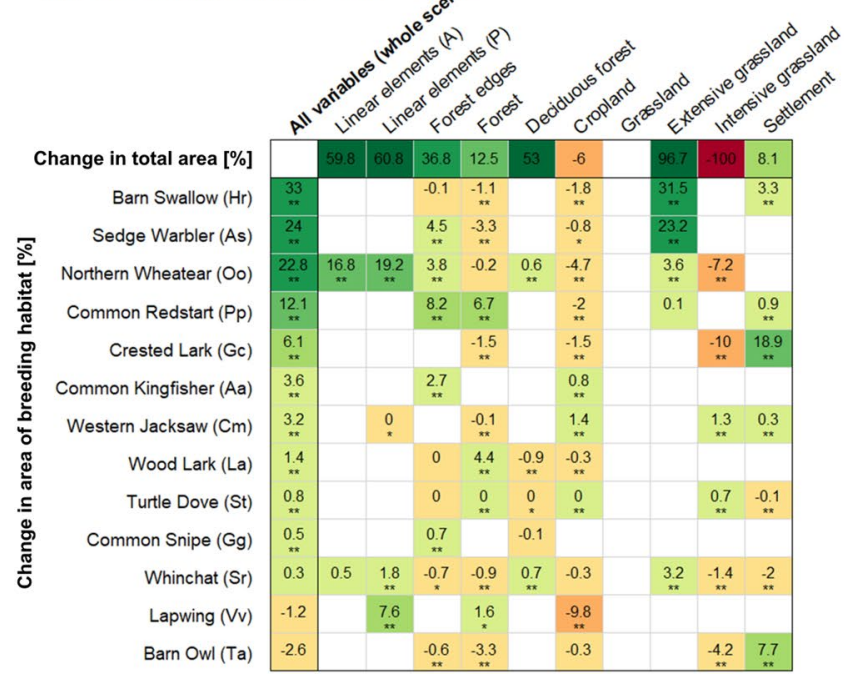

Legend

Change in respect to status quo (status quo $=100 \%$ )

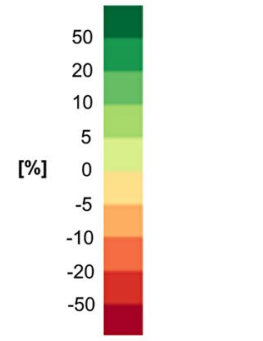

Fig. 2 Modeled changes in breeding habitat according to future landuse scenarios. Left columns show the modeled change in the size of the breeding habitat (\%). Top rows show the change (\%) of each land-use variable compared to the status quo. Central cells indicate the relative contribution (\%) of each land-use variable to the modeled change in habitat area according to permutation tests. For example,

the increase of forest area and forest edges (in particular in LSP, but also LSH). With regard to grasslands, both the loss of grassland in the LSP scenario and the increase in extensively managed grasslands in the LSH scenario can have positive effects on habitat area-depending on habitat preferences. On the contrary, for species losing habitat, this was mainly due to cropland losses and settlement expansion (LBA scenario) as well as the loss of (extensively used) grasslands and forest expansion (LSP scenario). With the exception of the LBA scenario, changes in linear landscape elements were of minor importance. In summary, the the habitat area of the crested lark increased by $53.8 \%$ in the LBA scenario, mainly caused by the $24.4 \%$ increase in settlement area, which explains $61.4 \%$ of the modeled change in habitat area. If the cells are empty, the corresponding land-use variables were not used in the models. Significance levels: ${ }^{*} p<0.05$, $* * p<0.01$

proportion of extensively managed permanent grassland and the density of forest edges were the variables that had positive effects on most species when they increased and negative effects when they decreased (Fig. 2, Fig. 3).

\section{Discussion}

This model-based analysis helps us understand how potential land-use changes represented by stakeholder-defined scenarios in an agricultural landscape affect the habitat 
(a)

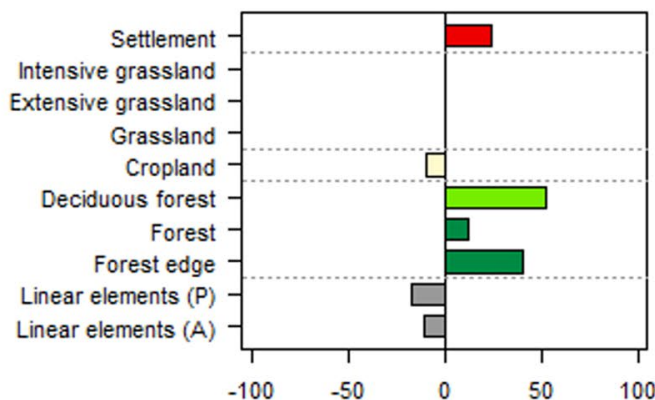

(b)

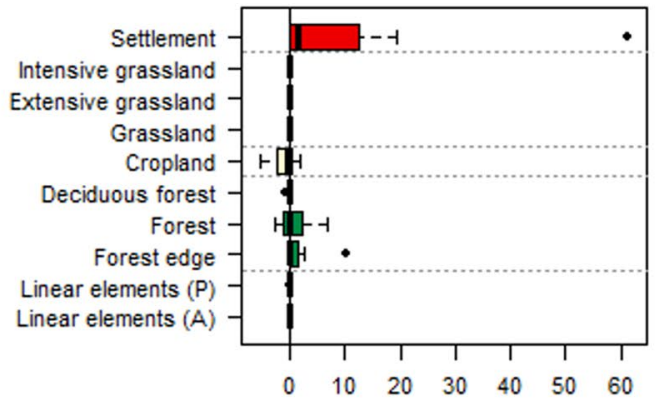

(c)

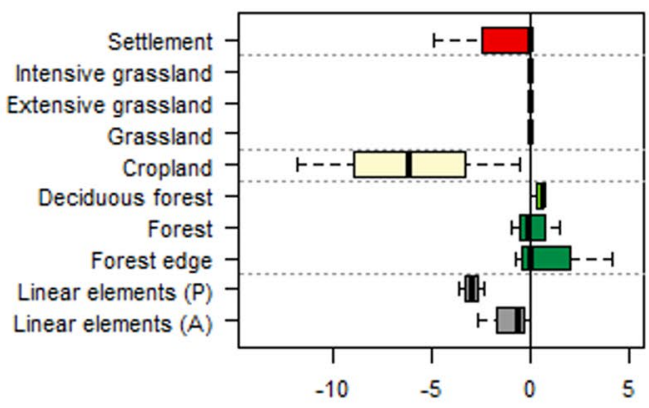

[\%]

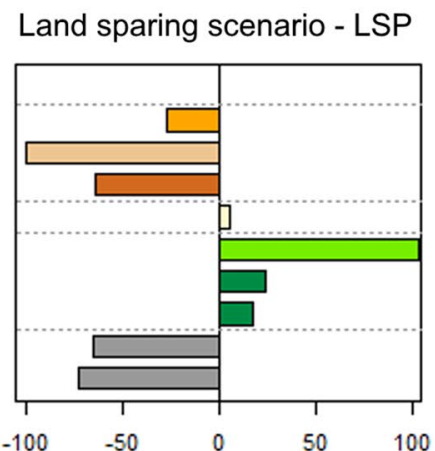

[\%]

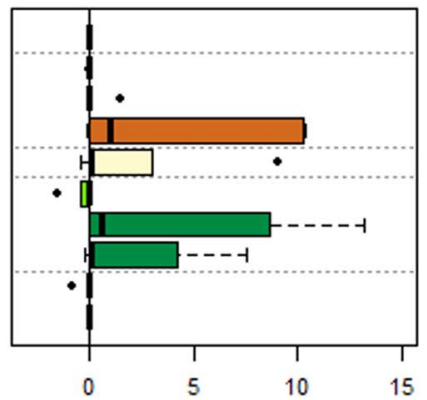

[\%]

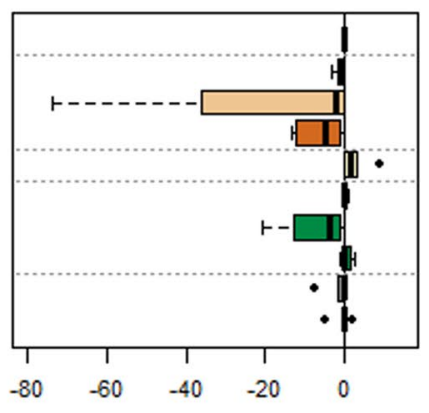

[\%]
Land sharing scenario - LSH

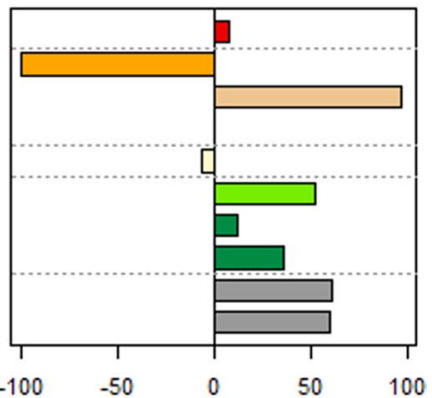

[\%]

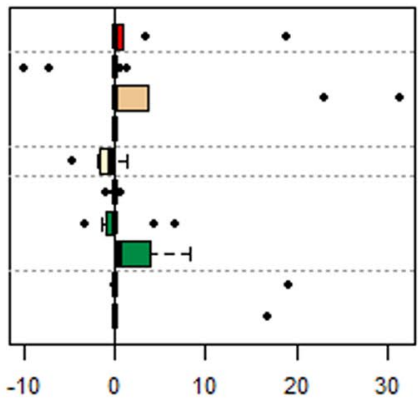

[\%] no species with
significant breeding
habitat loss
Fig. 3 Summarized effects of future land-use scenarios on the size of breeding habitat of 13 endangered bird species. (a) Proportional changes (\%) in individual land-use variable between the status quo land use and the scenarios. Middle and bottom panels summarize relative contributions (\%) of each land-use variable to the modelled change in habitat area according to permutation tests for (b) species with significant habitat gain and (c) species with significant habitat loss

biodiversity conservation goals of protected areas (Kremen and Merenlender 2018).

\section{Importance of land-use changes}

The complexity of conserving biodiversity across multiple species or taxa is well represented in our study, as the analyzed dataset of regionally endangered birds comprises farmland species (a predominant category in a region with substantial areas of anthropogenic farmed habitats), as well as shrubland-, woodland-, and wetland-associated species (Table 1). Our study species depend upon different ecological niches and therefore respond to diverse pressures 
and threats. Our analysis showed that higher proportions of extensively managed permanent grassland and the density of forest edges had positive impacts on most bird species. This aligns with our expectations, as the majority of the species in our dataset are associated with open dry or wet habitats (Table 1). Two species in particular (barn swallow and sedge warbler) were heavily dependent on extensively used grasslands. Benefits seem to arise for the barn swallow both from presence of domestic animals per se, and from availability of nesting sites and foraging areas in the grasslands (Musitelli et al. 2016). A priority for bird conservation is thus to ensure that grassland habitats are protected from conversion to cropland (Kamp et al. 2015). Grassland and fallow land areas were especially important for farmland species in our study, and their loss has been identified as the main driver of farmland bird declines in Germany and across Europe (Busch et al. 2020). In addition, the intensity of grassland management is a key factor influencing bird diversity. Intensively used grasslands provide less food (seeds, invertebrates) and fewer nesting opportunities for ground-breeding species (Vickery et al. 2001). Although we could only consider a binary classification of land-use intensity (intensive vs. extensive grasslands), our results show that extensively managed grasslands are essential for maintaining bird habitat in agricultural landscapes.

Forest edges and linear landscape elements like tree rows and hedges are important features in European agricultural landscapes, often having higher species richness and supporting many rare bird species (Terraube et al. 2016). While the density of forest edges was a relevant predictor for $77 \%$ of the considered species, the extent of linear landscape elements influenced only $30 \%$ of them. Linear landscape elements included in the ATKIS Basis DLM are often alleys in which low-hanging branches and shrubs are cleared for visibility and traffic safety reasons, which may severely limit their value for biodiversity conservation. In comparison, forest edges represent a relatively undisturbed habitat in our study region, with a complex vegetation structure and mature undergrowth of hedge species and grasses.

Five species benefited from the expansion of the settlement area whereas only two species (turtle dove and whinchat) were negatively affected by it. Rural villages are often overlooked as biodiversity hotspots (Rosin et al. 2016) and can be, in many cases, regarded as more biodiversityfriendly than intensively used agricultural areas because they offer various habitat types and contain numerous niches. The Middle Mulde River Basin is an area with many small villages, typically with one-family dwellings with surrounding gardens, and some towns, of which the largest is Döbeln with around 24,000 residents. All study species that benefited from the settlement expansion are known to prefer this environment for nesting. Thus, the increase of the settlement area in this region is not necessarily harmful for bird diversity as such if adequate nesting opportunities and food sources are provided.

Based on our results, the LSH scenario provided the largest increase in total breeding habitat across species. This is in contrast to similar studies in agricultural regions of England and Poland, in which LSP outperformed LSH in its effects on bird population sizes (Feniuk et al. 2019; Finch et al. 2019). However, both studies present how a mixed strategy that combines high-yield farming, natural habitat, and low-yield farming often outperforms both LSH and LSP. Low-yield farming is indeed an essential habitat for farmland birds, and our results showed how the increases of extensive grassland, landscape elements, and forest edges in the LSH scenario are the drivers of the breeding habitat expansion for most species in our dataset (Fig. 3). Most species in our analysis are openland species, and our results may have differed substantially with the inclusion of more forest and wetland species. We focused on endangered bird species in a region with a substantial extent of human-altered habitat as one effective strategy to minimize local species loss in the near future, by protecting the habitat of those species which are most sensible. Our results highlight that, in such a region, an LSH strategy is the best to mitigate, or stop, breeding habitat loss for the regionally endangered birds considered here.

\section{Evaluation of the scenarios by the stakeholders}

We discussed the developed spatially explicit representations of the land-use scenarios and the model results in a second workshop with the same stakeholders. All participants agreed that the most likely future development would be similar to the LBA scenario, since no major changes regarding land use and current policies are expected (Karner et al. 2019). The LSP scenario was perceived as unrealistic due to the drastic transformations in land-use change trends (e.g. soil sealing and afforestation) from the present situation. The participants agreed that the LSH scenario (which provided the largest habitat area according to our findings) is indeed the most desired future for the Middle Mulde River Basin due to the reduction in land-use intensity and the presumed benefits for biodiversity and ecosystem functioning. However, in order to achieve land use as in the LSH scenario, stakeholders pointed out that remarkable changes in local and regional decision-making and in agricultural policy in general would be necessary. This is true also at the international level. The current CAP supports wildlife-friendly farming practises, such as crop diversification, maintenance of permanent grassland, implementation and maintenance of Ecological Focus Areas (EFAs) and Agri-environmentclimate schems (AESs), and payments for organic farming. However, to the extent at which they are currently implemented, such measures have proven insufficient in halting 
biodiversity loss and ecosystem degradation related to agricultural expansion and intensification (Pe'er et al. 2014). Though the recently adopted regulations for the period 2023-2027 are promoted as a 'greener CAP' (European Commission 2021), it has to be seen if and how the new CAP will in practice result in more widespread adoption of extensive and biodiversity-supporting agricultural practices.

\section{Future research directions}

The crop type and the complexity of the crop rotation are of key importance for the habitat quality of birds (Jerrentrup et al. 2017). While field-scale mapping of crop types is possible with the latest remote sensing imagery (Griffiths et al. 2019), the bird data used here related to the period 2003-2008, so it was unfortunately not possible to include such information here. Previous empirical studies have shown that increased nitrogen fertilizer and pesticide use on cropland has a negative impact on the abundance of farmland birds (e.g. Billeter et al. 2008). It will be crucial to include such information in future analyses in order to refine the results of this study. We also suggest that future studies should aim at differentiating the structure and quality of linear landscape elements to provide more detailed information on these important landscape features. While habitat loss is one of the main causes of farmland bird decline, we encourage future research to investigate the relationship between habitat availability and population size of different species, to estimate what is the minimum habitat area needed for species subsistence in the region. This can be done by modeling bird abundances (Finch et al. 2021), rather than occurrences as in our study, or by developing metrics to link area of habitat to likelihood of local population persistence (Durán et al. 2020).

\section{Conclusions}

This study contributes to our understanding of the effects of land use on birds in agricultural landscapes in several aspects. It is one of the few studies that uses stakeholderdriven land-use scenarios on LSH and LSP and combines them with a state-of-the-art species distribution modeling approach. The variable responses of individual bird species to changes in agricultural land use in our study illustrate the complexity of conserving biodiversity across multiple species or taxa. We agree with others (Rey Benayas and Bullock 2012; Fischer et al. 2014) that the dichotomy of LSH vs. LSP is too simplistic and that these management strategies should be combined to best reconcile crop production and biodiversity conservation, as also supported by recent empirical findings (Feniuk et al. 2019; Finch et al. 2021). While areas of natural and semi-natural habitats are of pivotal importance for species subsistence and should be protected from further anthropogenic encroachment, the integration of agricultural production and biodiversity conservation can be achieved by applying less-intensive, wildlife-friendly land-use strategies (Walker et al. 2018; Busch et al. 2020). Stakeholders particularly valued the reduction in land-use intensity and the benefits for biodiversity and ecosystem functioning in the LSH scenario, which provided the largest total habitat area for the bird species considered here. Already existing schemes like organic farming and AESs can be effective tools in combating biodiversity decline in agricultural landscapes, if appropriate funding, widespread uptake (through stakeholder support), and continuous monitoring of biodiversity responses are ensured at the regional, national, and international scale. To achieve this, however, significant changes in local and regional decision-making and in agricultural policy in general would be required.

Supplementary Information The online version contains supplementary material available at https://doi.org/10.1007/s10113-022-01878-3.

Author contribution A.J., A.F.C., M.S., and M.V. conceived the idea and designed the methodology; A.J. and M.S. prepared the data; T.V. produced the land-use scenarios; A.J. implemented the models; A.F.C., S.R., and A.J. led the writing of the manuscript. All authors contributed critically to the drafts and gave final approval for publication.

Funding Open access funding enabled and organized by Projekt DEAL. We thank the Saxon State Agency for Environment, Agriculture and Geology for providing the bird data. This research was partly funded through the 2013-2014 BiodivERsA/FACCE-JPI joint call for research proposals, with the national funder German Federal Ministry of Education and Research (BMBF) (Förderkennzeichen 01LC1404). This work was also supported by European Union's Horizon 2020 research and innovation programme grant agreement no. 817501 (BESTMAP) and the project "SustES - Adaptation strategies for sustainable ecosystem services and food security under adverse environmental conditions" (CZ.02.1.01/0.0/0.0/16_019/0000797).

Open Access This article is licensed under a Creative Commons Attribution 4.0 International License, which permits use, sharing, adaptation, distribution and reproduction in any medium or format, as long as you give appropriate credit to the original author(s) and the source, provide a link to the Creative Commons licence, and indicate if changes were made. The images or other third party material in this article are included in the article's Creative Commons licence, unless indicated otherwise in a credit line to the material. If material is not included in the article's Creative Commons licence and your intended use is not permitted by statutory regulation or exceeds the permitted use, you will need to obtain permission directly from the copyright holder. To view a copy of this licence, visit http://creativecommons.org/licenses/by/4.0/.

\section{References}

Barbet-Massin M, Jiguet F, Albert CH, Thuiller W (2012) Selecting pseudo-absences for species distribution models: how, where and how many? Methods Ecol Evol 3:327-338. https://doi.org/ 10.1111/j.2041-210X.2011.00172.x 
Batáry P, Gallé R, Riesch F, Fischer C, Dormann CF et al (2017) The former Iron Curtain still drives biodiversity-profit trade-offs in German agriculture. Nat Ecol Evol 1:1279-1284. https://doi.org/ 10.1038/s41559-017-0272-X

Bennett NJ, Kadfak A, Dearden P (2016) Community-based scenario planning: a process for vulnerability analysis and adaptation planning to social-ecological change in coastal communities. Environ Dev Sustain 18:1771-1799. https://doi.org/10.1007/S10668-0159707-1/TABLES/4

Bieger K, Arnold JG, Rathjens H, White MJ, Bosch DD et al (2017) Introduction to SWAT+, a completely restructured version of the soil and water assessment tool. JAWRA J Am Water Resour Assoc 53:115-130. https://doi.org/10.1111/1752-1688.12482

Billeter R, Liira J, Bailey D, Bugter R, Arens P et al (2008) Indicators for biodiversity in agricultural landscapes: a pan-European study. J Appl Ecol 45:141-150. https://doi.org/10.1111/j.13652664.2007.01393.x

Brambilla M, Ficetola GF (2012) Species distribution models as a tool to estimate reproductive parameters: a case study with a passerine bird species. J Anim Ecol 81:781-787. https://doi. org/10.1111/J.1365-2656.2012.01970.X

Breiman L (2001) Random forests. Mach Learn 45:5-32. https://doi. org/10.1023/A:1010933404324

Busch M, Katzenberger J, Trautmann S, Gerlach B, Dröschmeister R et al (2020) Drivers of population change in common farmland birds in Germany. Bird Conserv Int 30:335-354. https://doi.org/ 10.1017/S0959270919000480

Chapron G, Kaczensky P, Linnell JDC, Von Arx M, Huber D et al (2014) Recovery of large carnivores in Europe's modern humandominated landscapes. Science 346:1517-1519. https://doi.org/ $10.1126 /$ science. 1257553

Durán AP, Green JMH, West CD, Visconti P, Burgess ND et al (2020) A practical approach to measuring the biodiversity impacts of land conversion. Methods Ecol Evol 11:910-921. https://doi.org/10.1111/2041-210X.13427

Eckelmann W, Sponagel H, Grottenthaler W (2005) Manual of soil mapping, 5th Ed. (KA5). Schweizerbart Science Publishers, Stuttgart.

Egli L, Meyer C, Scherber C, Kreft H, Tscharntke T (2018) Winners and losers of national and global efforts to reconcile agricultural intensification and biodiversity conservation. Glob Chang Biol 24:2212-2228. https://doi.org/10.1111/GCB.14076

Elith J, Graham HC, Anderson PR, Dudík M, Ferrier S et al (2006) Novel methods improve prediction of species' distributions from occurrence data. Ecography 29:129-151. https://doi.org/ 10.1111/j.2006.0906-7590.04596.x

Elith J, Leathwick JR (2009) Species distribution models: ecological explanation and prediction across space and time. Annu Rev Ecol Evol Syst 40:677-697. https://doi.org/10.1146/ANNUR EV.ECOLSYS.110308.120159

Ernst LM, Tscharntke T, Batáry P (2017) Grassland management in agricultural vs. forested landscapes drives butterfly and bird diversity. Biol Conserv 216:51-59. https://doi.org/10.1016/J. BIOCON.2017.09.027

European Commission (2021) The new common agricultural policy: 2023-27. https://ec.europa.eu/info/food-farming-fisheries/keypolicies/common-agricultural-policy/new-cap-2023-27_en\# documents. Accessed 21 December 2021.

Feniuk C, Balmford A, Green RE (2019) Land sparing to make space for species dependent on natural habitats and high nature value farmland. Proc R Soc B Biol Sci 286. https://doi.org/10.1098/ rspb.2019.1483

Finch T, Gillings S, Green RE, Massimino D, Peach WJ et al (2019) Bird conservation and the land sharing-sparing continuum in farmland-dominated landscapes of lowland England. Conserv Biol 33:1045-1055. https://doi.org/10.1111/cobi.13316
Finch T, Green RE, Massimino D, Peach WJ, Balmford A (2020) Optimising nature conservation outcomes for a given regionwide level of food production. J Appl Ecol 57:985-994. https:// doi.org/10.1111/1365-2664.13594

Finch T, Day BH, Massimino D, Redhead JW, Field RH et al (2021) Evaluating spatially explicit sharing-sparing scenarios for multiple environmental outcomes. J Appl Ecol 58:655-666. https:// doi.org/10.1111/1365-2664.13785

Fischer J, Abson DJ, Butsic V, Chappell MJ, Ekroos J et al (2014) Land sparing versus land sharing: moving forward. Conserv Lett 7:149-157. https://doi.org/10.1111/CONL.12084

Fletcher R, Fortin M (2018) Spatial ecology and conservation modeling. Springer International Publishing. https://doi.org/10.1007/ 978-3-030-01989-1

Gabriel D, Sait SM, Kunin WE, Benton TG (2013) Food production vs. biodiversity: comparing organic and conventional agriculture. J Appl Ecol 50:355-364. https://doi.org/10.1111/1365-2664.12035

Gillings S, Henderson IG, Morris AJ, Vickery JA (2010) Assessing the implications of the loss of set-aside for farmland birds. Ibis 152:713-723. https://doi.org/10.1111/J.1474-919X.2010.01058.X

Gregorutti B, Michel B, Saint-Pierre P (2017) Correlation and variable importance in random forests. Stat Comput 27:659-678. https:// doi.org/10.1007/s11222-016-9646-1

Griffiths P, Nendel C, Hostert P (2019) Intra-annual reflectance composites from Sentinel-2 and Landsat for national-scale crop and land cover mapping. Remote Sens Environ 220:135-151. https:// doi.org/10.1016/J.RSE.2018.10.031

Hijmans RJ, Phillips S, Leathwick JR, Elith J (2017) dismo: species distribution modeling. R package version 1.1-4. https://CRAN.Rproject.org/package $=$ dismo

Jerrentrup JS, Dauber J, Strohbach MW, Mecke S, Mitschke A et al (2017) Impact of recent changes in agricultural land use on farmland bird trends. Agric Ecosyst Environ 239:334-341. https://doi. org/10.1016/J.AGEE.2017.01.041

Jiang H, Eastman JR (2000) Application of fuzzy measures in multicriteria evaluation in GIS. Int J Geogr Inf Sci 14:173-184. https:// doi.org/10.1080/136588100240903

Jolibert C, Wesselink A (2012) Research impacts and impact on research in biodiversity conservation: the influence of stakeholder engagement. Environ Sci Policy 22:100-111. https://doi.org/10. 1016/J.ENVSCI.2012.06.012

Kamp J, Urazaliev R, Balmford A, Donald PF, Green RE et al (2015) Agricultural development and the conservation of avian biodiversity on the Eurasian steppes: a comparison of land-sparing and land-sharing approaches. J Appl Ecol 52:1578-1587. https://doi. org/10.1111/1365-2664.12527

Karner K, Cord AF, Hagemann N, Hernandez-Mora N, Holzkämper A et al (2019) Developing stakeholder-driven scenarios on land sharing and land sparing - Insights from five European case studies. J Environ Manage 241:488-500. https://doi.org/10.1016/j.jenvm an.2019.03.050

Kleijn D, Kohler F, Báldi A, Batáry P, Concepción ED et al (2012) On the relationship between farmland biodiversity and land-use intensity in Europe. Proc R Soc B Biol Sci 276:903-909. https:// doi.org/10.1098/rspb.2008.1509

Kremen C, Merenlender AM (2018) Landscapes that work for biodiversity and people. Science 362:6412. https://doi.org/10.1126/ science.aau6020

Kuhn M (2016) caret: classification and regression training. R package Version 6.0-68. https://CRAN.R-project.org/package $=$ caret

Liaw A, Wiener M (2002) Classification and regression by randomForest. R News 2:18-22

Macchi L, Grau HR, Zelaya PV, Marinaro S (2013) Trade-offs between land use intensity and avian biodiversity in the dry Chaco of Argentina: a tale of two gradients. Agric Ecosyst Environ 174:1120. https://doi.org/10.1016/j.agee.2013.04.011 
Manning P, Van Der Plas F, Soliveres S, Allan E, Maestre FT et al (2018) Redefining ecosystem multifunctionality. Nat Ecol Evol 2:427-436. https://doi.org/10.1038/s41559-017-0461-7

Meinel G, Schumacher U, Behnisch M, Krüger T (2018) Flächennutzungsmonitoring X: Flächenpolitik - Flächenmanagement Indikatoren. Leibniz-Institut für ökologische Raumentwicklung e.V. (IÖR).

Mi C, Huettmann F, Guo Y, Han X, Wen L (2017) Why choose random forest to predict rare species distribution with few samples in large undersampled areas? Three Asian crane species models provide supporting evidence. PeerJ. https://doi.org/10.7717/peerj.2849

Musitelli F, Romano A, Møller AP, Ambrosini R (2016) Effects of livestock farming on birds of rural areas in Europe. Biodivers Conserv 25:615-631. https://doi.org/10.1007/s10531-016-1087-9

Pe'er G, Dicks LV, Visconti P, Arlettaz R, Báldi A et al (2014) EU agricultural reform fails on biodiversity. Science 344(10901092):1092. https://doi.org/10.1126/science. 1253425

Phalan B, Onial M, Balmford A, Green RE (2011) Reconciling food production and biodiversity conservation: land sharing and land sparing compared. Science 333:1289-1291. https://doi.org/10. 1126/SCIENCE.1208742/SUPPL_FILE/PHALAN.SOM.PDF

R Core Team (2016) R: A language and environment for statistical computing. R Foundation for Statistical Computing, Vienna, Austria.

Ranc N, Santini L, Rondinini C, Boitani L, Poitevin F et al (2017) Performance tradeoffs in target-group bias correction for species distribution models. Ecography 40:1076-1087. https://doi.org/10. 1111/ecog.02414

Rey Benayas JM, Bullock JM (2012) Restoration of biodiversity and ecosystem services on agricultural land. Ecosyst 156(15):883899. https://doi.org/10.1007/S10021-012-9552-0

Richter D (1995) Ergebnisse methodischer Untersuchungen zur Korrektur des systematischen Messfehlers des Hellmann-Niederschlagsmessers. Berichte des Deutschen Wetterdienstes, Offenbach.

Rosin ZM, Skórka P, Pärt T, Żmihorski M, Ekner-Grzyb A et al (2016) Villages and their old farmsteads are hot spots of bird diversity in agricultural landscapes. J Appl Ecol 53:1363-1372. https://doi. org/10.1111/1365-2664.12715

Sächsisches Landesamt für Umwelt, Landwirtschaft und Geologie (LfULG) (2011) Digitale Daten der besonderen Schutzgebiete (SAC) gem. FFH-Richtlinie (92/43/EWG) des Freistaates Sachsen (Stand 04/2011). https://www.natur.sachsen.de/schutzgebiete-insachsen-7050.html. Accessed 21 December 2021.

Sächsisches Landesamt für Umwelt, Landwirtschaft und Geologie (LfULG) (2015) Rote Liste der Wirbeltiere Sachsens (Dezember 2015). https://www.natur.sachsen.de/download/natur/RL_Wirbe 1tiereSN_Tab_20160407_final.pdf. Accessed 20 June 2016.

Scariot A (2013) Land sparing or land sharing: the missing link. Front Ecol Environ 11:177-178. https://doi.org/10.1890/13.WB.008
SMUL (2016) Waldstrategie 2050 für den Freistaat Sachsen. Dresden.

Steffens R, Saemann D, Grössler K (1998) Die Vogelwelt Sachsens. Gustav Fischer Verlag, Jena

Steffens R, Nachtigall W, Rau S, Trapp H, Ulbricht J (2013) Brutvögel in Sachsen. Sächsisches Landesamt für Umwelt, Landwirtschaft und Geologie, Dresden.

Stjernman M, Sahlin U, Olsson O, Smith HG (2019) Estimating effects of arable land use intensity on farmland birds using joint species modeling. Ecol Appl 29:1-18. https://doi.org/10.1002/eap.1875

Terraube J, Archaux F, Deconchat M, van Halder I, Jactel H et al (2016) Forest edges have high conservation value for bird communities in mosaic landscapes. Ecol Evol 6:5178-5189. https:// doi.org/10.1002/ECE3.2273

Ulbricht J (2018) Berichte zum Vogelmonitoring in Sachsen - Heft 1. Sächsisches Landesamt für Umwelt, Landwirtschaft und Geologie, Dresden.

Vallecillo S, Maes J, Polce C, Lavalle C (2016) A habitat quality indicator for common birds in Europe based on species distribution models. Ecol Indic 69:488-499. https://doi.org/10.1016/j.ecolind. 2016.05.008

Vickery JA, Tallowin JR, Feber RE, Asteraki EJ, Atkinson PW et al (2001) The management of lowland neutral grasslands in britain: effects of agricultural practices on birds and their food resources. J Appl Ecol 38:647-664. https://doi.org/10.1046/j.1365-2664. 2001.00626.x

Vogler D, Macey S, Sigouin A (2017) Network of conservation educators \& practitioners stakeholder analysis in environmental and conservation planning. Lessons Conserv 7:5-16

Volkery A, Ribeiro T, Henrichs T, Hoogeveen Y (2008) Your vision or my model? Lessons from participatory land use scenario development on a European scale. Syst Pract Action Res 21:459-477. https://doi.org/10.1007/S11213-008-9104-X

Walker LK, Morris AJ, Cristinacce A, Dadam D, Grice PV et al (2018) Effects of higher-tier agri-environment scheme on the abundance of priority farmland birds. Anim Conserv 21:183-192. https://doi. org/10.1111/acv.12386

Wilson S, Mitchell GW, Pasher J, McGovern M, Hudson MAR et al (2017) Influence of crop type, heterogeneity and woody structure on avian biodiversity in agricultural landscapes. Ecol Indic 83:218-226. https://doi.org/10.1016/j.ecolind.2017.07.059

Zabel F, Delzeit R, Schneider JM, Seppelt R, Mauser W et al (2019) Global impacts of future cropland expansion and intensification on agricultural markets and biodiversity. Nat Commun 10:1-10. https://doi.org/10.1038/s41467-019-10775-Z

Publisher's Note Springer Nature remains neutral with regard to jurisdictional claims in published maps and institutional affiliations. 